\title{
The Manifesto and Globalization
}

\author{
by Claudio Katz* \\ Translated by Carlos Pérez**
}

The Communist Manifesto anticipated the present process of globalization, and the subsequent theory of imperialism provides a more direct theoretical foundation for understanding it than the theories associated with Keynesianism, which approach

economic problems in purely national terms. This article ${ }^{1}$ emphasizes the relationship between the incipient globalization of the productive process and the laws of capitalist development, questioning the apologetic neoliberal view of globalization. It links the transformation of the division of the labor process, new forms of investment, mergers, and technological changes to an increase in the internationalization of production and underscores how this process contributes to increasing exploitation, unemployment, and poverty. It points to the difficulty of analyzing globalization from a purely commercial or financial perspective. In addition, it examines the problems associated not only with a dogmatic denial of the new phenomenon but also with characterizing it exclusively in political terms. It concludes by emphasizing the continuing relevance of the Manifesto for the construction of a socialist project based on the politics of working-class internationalism.

The paragraphs of the Communist Manifesto devoted to the worldwide expansion of capitalism continue to impress commentators on the text. Marx and Engels's (1967) 1848 descriptions of the creation of a world market, economic cosmopolitanism, the universal extension of commercial rules, and the destruction of tariff barriers have a surprisingly contemporary ring to them. The Manifesto anticipated the international character of accumulation with the same insight as Capital presaged the cyclical crises of capitalism. On many levels, these two texts have a deeper correspondence with our present economic reality than with that of the nineteenth century.

*Claudio Katz, an economist, is a professor and researcher at the University of Buenos Aires and Argentina's National Council of Scientific and Technical Investigations.

**Carlos Pérez teaches Chicano and Latin American Studies at California State University, Fresno. 


\section{A PROPOSAL IN EVOLUTION}

However, the important predictions that the Manifesto contains do not make it a picture of globalization today. This overstatement places the text outside of its own history. Alongside The Poverty of Philosophy and "Wage-Labor and Capital," the Manifesto is situated at the midpoint of the maturation of Marx's economic thought (Mandel, 1967). During this period the German theorist had elaborated his critique of private property, discovered the centrality of labor, transcended the anthropological analysis of alienation, and grasped the usefulness of the materialist conception of history. He had not yet assimilated or gone beyond Ricardo's ideas, however, and he had not reformulated the labor theory of value or that of surplus value. His analysis of the workings of capitalism was clearly evolving, and it contained certain characterizations that would subsequently be modified and refined.

The analogy between the worker and the slave that appears in the Manifesto has, for example, points of agreement with Ricardo's "subsistence salary." Salary is not yet characterized as a sociohistorical reality impacted contradictorily by accumulation and one whose evolution is associated with the changing value of the labor force. This is why the thesis of "growing misery" emerges in place of the subsequent concept of the relative decline of wages in relation to profit and the level of accumulation. Given that the general analysis of the process of value had not yet been completed, crises are presented in the Manifesto as exclusively the effect of under-consumption, without consideration of the constriction of purchasing power with the declining rate of profit. Some of these shortcomings are also observed in the concept of the process of global accumulation.

In his mature works, Marx completes his characterization of the intrinsic tendency of capital to break down national borders with more precise studies on the world market (Marx, 1973). On one hand, he discovers how the different modes of primitive accumulation led to the consolidation of industrial capital in the advanced countries. On the other hand, he tackles some of the problems associated with international commerce in opposition to Ricardo's thesis of "comparative advantage." He establishes the foundations for a theory of unequal exchange by emphasizing that the compensation of higher labor productivity is greater than that of lower labor productivity.

All of these ideas correspond to Marx's predominantly national analysis of capitalism. His study of tariffs, wages, prices, and capital movement assumes an industrialized national economy modeled on Britain's. The most significant aspect of this period of free trade on the international level is the role of commerce in the configuration of the distinct processes of national accumulation. Although Marx furnishes the basic theoretical elements for an understanding of globalization, his writings only sketch the bare outlines of such an understanding. 


\section{IMPERIALISM}

The immediate antecedents of the current discussion of globalization are found in the theory of imperialism formulated in the early twentieth century by Lenin, Luxemburg, Bukharin, and Trotsky. Their analysis sought an interpretation of the great transformation that occurred when monopoly replaced free-trade capitalism. This change was based on an important advancement in the internationalization of the economy, especially on the commercial and financial level, as well as on the development of the first forms of direct investment. The four theorists postulated convergent characterizations of a single phenomenon but highlighted different and controversial aspects of the new stage.

For Lenin (1973), the international expansion of capital implied the parasitic predominance of financial capital along with the creation of monopolies that stifled free trade. For Luxemburg (1968), what was important was the core nations' reaction to underconsumption-exporting their unsold surplus to the periphery. She believed that the collapse of these compensatory peripheral markets led to a point in the crises of profitability where there would be a characteristic decline.

Bukharin (1971), in contrast, saw a new type of contradiction emerging under capitalism as a result of the conflict between the persistence of national forms of appropriating profit and increasing economic internationalization. He emphasized that the monopolistic groups that globalized their networks of supplies, production, and commercialization tended to coalesce around increasingly protectionist states. He believed that this process produced not only the "internationalization" of capital but also its "nationalization."

Trotsky's (1972) initial analysis underscored that the primary consequence of the creation of a unified world market was a widening of the gulf between the developed and the underdeveloped countries. He asserted that this polarization drastically reduced the peripheral countries' opportunity for replicating the accelerated industrial development of the central powers. With the construction of a world capitalist system, Trotsky concluded, it was impossible to isolate a triumphant revolution's socioeconomic development from international conditions, and this is why he considered the attempt to "construct socialism in one country" utopian (Trotsky, 1969). He understood that the new imperialist stage demanded a revision of the strategy and project of socialism on a world scale. 
These four interpretations represent the theoretical foundations for an analysis of globalization because from different angles they characterize the transformations that capital penetration introduces into all corners of the world. To assess these contributions, however, it is necessary to separate their circumstantial elements from their essential components. A lasting contribution of Lenin's theory is the proposal of a transformation from free competition to a rivalry between monopolies as opposed to the idea that finance capital will subjugate industrial capital. The growing need for markets of the imperialist powers and their recourse to the oppression of the underdeveloped nations is the most valuable aspect of Luxemburg's work and not her vision of a crisis exclusively derived from the "collapse of the noncapitalist regions."

The contradiction between the internationalization of the productive forces and the persistence of national boundaries effectively constitutes the core explanation for the great worldwide economic and military conflicts, but the forms of these conflicts have substantially changed since Bukharin's time. Trotsky's view of the growing polarization between oppressed and oppressor nations has survived, and so has his focus on the unfeasibility of any socialist project that is conceived in purely national terms. This process does not imply a prolonged stagnation of the productive forces, as was believed in the 1930s, but rather its opposite. What has emerged is the increasing difficulty of reconciling the intensification of production and of productivity with the spread of markets and the expansion of profits. By separating the central elements of an analysis of imperialism from the characteristics it assumed during the interwar period one can arrive at the essential theoretical core that permits us to advance a contemporary interpretation of globalization.

\section{KEYNESIANISM}

During the postwar period, analyzing capitalism in solely national terms once again predominated. This focus represented the continuity of the protectionist course initiated in the 1930s and, especially, the primacy of interventionist economic policies in the major nations. Keynesianism, which nurtured this trend, approaches global economic problems (trade, fluctuations, investment flows, etc.) as an extension or derivation of a national focus. Neither macroeconomic categories nor fiscal and monetary policies are conceived outside of this framework.

The limitations of this focus for an understanding of globalization are obvious, especially because the world market is interpreted as a simple beneficiary of the "growing 
interdependence between nations" and not as a new site for global accumulation. The inadequacy of the Keynesian criteria for analyzing globalization is apparent also in the various schools, such as that of regulation (Boyer, 1997), that have sought to reconcile the tradition of Keynes with that of Marx. For example, the concepts "rule of accumulation" and "mode of accumulation" are restricted, by definition, to the national sphere, and the same is true of "Fordism," "Taylorism," and "post-Fordism." The classic opposition between the "Austrian model" and the "Anglo-Saxon neoliberal model" also place strategic national rivalries at the center of their analysis, overlooking the new conditioned reality of globalization.

This same difficulty also underlies the Stalinist proposal of reaching socialism through the "competition between two systems." In the same way as Keynesianism, this approach characterized the world economy as a meeting between distinct forms of accumulation struggling for supremacy. It failed to understand that the twentieth-century internationalization of the economy was not an amalgam of different national characteristics but a major new referential axis for every nation. Ignoring this reality made it possible to believe, mistakenly, that socialism could be constructed within the confines of a region, coexisting with capitalism or conquering it by the "successes achieved by the socialist bloc."

\section{GLOBALIZATION}

During the 1970s and 1980s the analysis of globalization was undertaken by studies that tried to update the theory of imperialism, incorporating the new role of corporations now designated "transnational firms." Michalet's work especially served to identify the appearance of a new type of firm that by strategically developing a single internationalized management can profit from national differences in productivity and salaries (Michalet, 1976). These corporations obtain extraordinary profits by constructing a homogeneous sphere within the fractured geographical environment in which their principal firms and branches operate. They are corporations that maintain their privileged links with their national states and headquarters but adopt the world market as the reference point for their activities by establishing an unprecedented internal circulation of capital, labor, inputs, and technology. These corporations have created a new international division of labor based on the principle of maximum extraction and realization of surplus value around themselves. They have introduced both increased uniformity and increased differentiation into the process of accumulation. On one hand, competition obliges them to increase the international distribution of their products, processes, innovations, and 
forms of management. On the other hand, to maintain their huge profits they must preserve the great international differences between productivity and salaries. The study of transnational firms based on new empirical data gathered by the United Nations Center for Transnational Corporations and proceeding from innovative theoretical reinterpretations, for example, of the "product cycle" generated the field of Marxist investigations of globalization. To a great extent, the most recent analyses of globalization have distorted or denied the significance of these investigations.

The abrupt rise of the term "globalization" signified the sanctification of an idea that refers not to a specific type of economic internationalization under capitalism but to a post-industrialist stage. It is assumed that in the era of "global communication" and "global marketing" industrial capitalism is being replaced by an "information society" in which property loses all significance and is replaced by information. In this view, the dynamics of the new "social actors" bury the class struggle, the nation-state loses its importance, and the market is transformed into the undeniable master of all human actions. The purely apologetic character of this approach is obvious, beginning with the elimination from the analysis of the very idea of globalization. Its most widely accepted ideas do not go beyond a rudimentary embellishment of "deregulation," privatization, or the "free market."

In a critical analysis, it is necessary to avoid the neoliberal superstitions that characterize the modern period. For example, authors like Sivanandan (1997) correctly question "social exclusion," the "marginalization" of the peripheral nations, or the "increase of inequalities," but erroneously accept the idea of a "trans-nationalization of the bourgeoisie." With this approach, globalization is identified with the emergence of a new capitalist class that is predominant and cohesive on a worldwide scale.

Advocates of this idea overlook the fact that with internationalization competitive pressure between firms increases, and so does the need to resort to the state for support to prevail in this struggle. They forget that the state structure is not weakened but reorganized on a geographical level and functionally restructured for its struggle for global hegemony.

\section{THE INTERNATIONALIZATION OF PRODUCTION}

The most significant characteristic of globalization in the past decades is the movement toward the internationalization of the productive process. Here is where the central differences between the current transformations and those of the first decades of the twentieth century lie. This transformation is related to the crisis of capitalism and its re- 
organization since the 1970s. Along with overproduction, the decline of long-term profitability, and the disjunction between production and consumption that contributed to the current crisis, there has been a restructuring of the main branches of industry in the core nations. A central component of this new environment is an increase in the internationalization of production.

This increase can be measured by observing the great multiplication of foreign investments directly managed by the 600 firms that control a third of the world's gross domestic product. Through subcontracting, "joint ventures," and aid contracts, these firms have expanded their control over all the international linkages of the manufacturing process and the sale of goods and services. This is not a strategy for supplying themselves with primary products or capturing markets through the establishment of branches but the initiation of what Andreff (1996) calls the "international decomposition of the production process," with each branch specializing in an operation that contributes to the global strategy of the company. It is for this reason that they generally place their high-quality activities in the developed countries and those of "Taylorist" type in underdeveloped ones.

Since the 1980s, the new international rivalry on the production level has caused a spectacular wave of mergers that have required reduction of costs and an increase in productivity. It has also produced an increase in the centralization of capital (in no important sector are there more than ten huge competitors operating), the formation of complexes that integrate services to industry's requirements, and the proliferation of agreements between firms to ensure the distribution of the various goods. The substitution of the label "Made in such-and-such a country" with "Made by such-and-such a company" symbolizes this transformation. The "global factory" and the "global product" are not yet the norm, but this is the central tendency of capitalism today.

An important theoretical implication of this process is the potential transformation in the determination of prices under the law of value. A significant portion of the production undertaken in the internal space of these internationalized firms is based on the "transfer price" administered by managers who are to some extent independent of market instability. Thus, a fracture emerges in the classical process of the determination of average profit and the costs of production based on national prices and currency, contributing to a regional structuring of new monetary standards and policies regarding subsidies and tariffs.

At the same time, the internationalization of production is responsible for the dynamic acceleration of innovation in the field of information technologies. It simultaneously constitutes a great stimulus to the ongoing technological revolution and is the determi- 
nant of its major contradictions (developed in Katz, 1998). On this point, two major ideas in the Manifesto have special relevance: the characterization of the bourgeoisie as a class that "cannot exist without constantly revolutionizing the means of production" and the appearance of an "epidemic of overproduction" as a consequence of this idiosyncrasy. Both phenomena are evident today. Under capitalism, the multiplication of new goods and forms of production is indissolubly linked to the production of surpluses in relation to the purchasing capacity of the population. It is for this reason that poverty, unemployment, and exploitation are increasing alongside the internationalization of the productive process. Latin America is one of the regions most affected by this transformation.

\section{FINANCE AND COMMERCE}

Some writers focus on "financial globalization" and link it with the emergence of a new "financier mode of production," emphasize that the disproportionate expansion of credit increasingly disassociates the financial processes from the "real economy." They maintain that financial capital subordinates industrial activities and that investment flows are fictitious, concealing operations that are purely speculative. This approach fails to recognize the methodological importance of arranging the analysis of the productive sphere hierarchically and privileging the study of the laws that operate there. The fruitful discussion that has recently emerged concerning this question (Husson, 1997; Chesnais, $1994 ; 1998)$ has been the background of the debates surrounding the "decline of U.S. imperialism" (Brenner, 1995; Malloy, 1995). On the specific level of globalization, the exclusive focus on finance tends to divorce the analysis of the "global banks" from the strategic constitution of "global firms."

Without a doubt, the expansion of the unproductive parasitism of financiers enriched by playing the stock market or raiding indebted countries is a fundamental reality of the present crisis. In condemning this pillaging, however, we should seek to understand the capitalist logic underlying it, and to do this we should focus on the productive sphere. All the major changes in financial globalization registered in the past few years are connected to its industrial determinant. This dependency is visible even in the description of the financial transformations that, for example, Philon (1997) observes. The banking intermediary is bypassed by a direct issuing of bonds by companies, thereby circumventing the need to acquire credit for investment purposes. The increasing deregulation of banking is facilitating this type of self-financing, while the liberalization of operations-eliminating their previous segmentation by type of activity-aims to facilitate fusion and the formation 
of financial-industrial holdings. It is evident that the issuing of credit independent of real economic transactions exacerbates the crisis, along with the capitalist demand to halt recession and aid bankrupt firms. The dynamics of accumulation orders the entire process and limits any margin of independence achieved by finance. Furthermore, it coexists with an inverse trend of a stricter adaptation of financial movement to the industrial demands of each participating company.

A similar neglect of the centrality of the production process appears in approaches to globalization that emphasize the progressive formation of a "world economy" resulting from the successive phases of "commercial globalization" (Adda, 1996). One loses sight of the fact that the increase in international transactions in contrast to production has occurred through the adaptation of commercial legislation (primarily liberalization by the General Agreement on Tariffs and Trade and the subsequent creation of the World Trade Organization and of regional markets without internal tariffs) to the demands of the internationalization of the productive process. The epicenter of this process is the movement of inputs and goods within the same corporations, and this requires a detailed study of the changes occurring in these firms' organization of production. The "world economy" approach has a tendency to assume that there is a continuity between the "first commercial globalization" of the sixteenth century and contemporary developments, making it difficult to perceive the specificity of today's internationalization of production.

\section{DOGMAS AND SUBJECTIVISM}

Some analysts go so far as to question the very existence of globalization. They maintain that internal markets continue to predominate in relation to exports, that protectionism persists as a habitual practice, that the level of the internationalization of production is less than what is usually believed, and that capitalism's cosmopolitanism is not new but is characteristic of the history of this social order. These ideas contain many allusions to the regulation school concerning the continuing "pull of the national space" in the contemporary period.

The data that they present in favor of these arguments are very useful in refuting the caricature of globalization created by neoliberal apologists. In opposing the image of a "completely new global world," the dogma of the invariability of capitalism is not very promising, especially if one remembers that the Manifesto clarifies the particularly dynamic and changing character of this mode of production. For this reason, instead of de- 
nying the appearance of a new economic reality, it is necessary to understand its principal tendencies. Globalization is a central characteristic of the contemporary period because it not only constitutes a source of huge profits for the principal firms but also responds to the current demands of accumulation. Unless its existence and the centrality to it of the production process are recognized it will be impossible to understand this era.

There is another approach that recognizes the importance of globalization but interprets it as primarily political and capable of being characterized as the "attack of capital on labor" (Holloway, 1998). The adherents of this point of view refuse to conceptualize it in terms of objective laws and propose to understand it by means of the class struggle alone (Bonefeld, 1998). But Marxism contextualizes the centrality of the class struggle within a framework of objective limits, circumstances, and possibilities. The Manifesto- as a political analysis of the revolutionary situation and potential of 1848-is an example of this methodology since it situates the conditions of the confrontation between the bourgeoisie and the proletariat in the particular framework of economic crisis. Modifying this framework is advocated by the prefaces to later editions when they declare that the document "has aged" and requires new articulations.

In contrast to the contemporary sociological style of replacing classes with various types of "actors," it is necessary to emphasize classes and their struggle as defining phenomena of the political process. This recognition constitutes a central legacy of the Manifesto that, for example, contributes to our understanding of the nexus that occurred between the leap in globalization and the relation of forces favorable to the bourgeoisie established in the 1980s and part of the 1990s. Reducing globalization to a purely political phenomenon obfuscates an interpretation of it in its totality as a process derived from the logic and laws of capital.

\section{WORKERS WITHOUT A COUNTRY}

Economic internationalization creates very favorable objective conditions for bringing the political actions of the world's workers together in a common program. When the Manifesto asserts that "workers are without a country" and for this reason they "act above any national differences," it is expressing a principle that has enormous relevance today. The same pressure that requires the bourgeoisie to equip itself on a worldwide scale with political instruments, forms of management, and methods of coercion contributes to the need for workers to organize their struggles and defend their rights on an international 
level. But what is a reality for the dominant class is scarcely considered a necessity for the dominated class. For a long time, corporations have been converting international (International Monetary Fund, United Nations, World Bank, World Trade Organization, and others) and regional (European Union, North American Free Trade Association, Association of South East Asian Nations, and others) organizations into "committees to administer their affairs" - the central characteristic that the Manifesto attributes to the modern state. Corporations are even discussing how to design a "multilateral investment accord" that will have constitutional powers to guarantee capitalist investments, property, and profits when confronted by any popular challenge in any corner of the world. In relation to the international spread of the bourgeoisie's forms of domination, the level of organization and actual consciousness of the worker is obviously very low. This political backwardness of the exploited is not new (and is the result of a combination of politicalhistorical factors whose analysis is beyond the scope of this article), but it has become a crucial question. All of the objective conditions exist for the globalization of the economy to serve as a point of departure for action to achieve the workers' just demands. A response on the same level as that on which the corporations operate would produce impressive results, and therefore the major problem is how to advance workers' political power through the organization of labor unions on an international scale. This structure must transcend the segmentation of professions, qualifications, nationality, race, ethnicity, and gender that is promoted and exacerbated by the dominant classes. In the age of "just in time" and "productive flexibility adjusted to demand," workers have increasing capacity to assert their demands through coordinated international actions, as current struggles for workers' rights in Europe and Latin America have begun to show.

The Manifesto's call for the workers of the world to unite is its most contemporary aspect. It is a message that is not limited to the circumstances of 1848 but responds to the oppressiveness of capitalism in every period and every country. Internationalism is the pillar for a revival of the socialist project of emancipation.

\section{NOTE}

This article was first written in November 1998. For a further treatment of globalization see also Claudio Katz's “Desequilibrios y antagonismos de la mundialización”in Ralidad Económica n. 178, febreromarzo 2001, Buenos Aires. 


\section{REFERENCES}

Adda, Jacques

1996 La mondialisation de l'économie. 2 vols. Paris: La Découverte.

Andreff, Wladimir

1996 Les multinationales globales. Paris: La Découverte.

Bonefeld, Werner

1998 "150 años: reflexionando en la ira." Cuadernos del Sur 26 (April).

Boyer, Robert

1997 "Les mots et les realites," in Mondialisation: Au-delà des mythes. Paris: La Découverte.

Brenner, Robert

1995 "The politics of U.S. decline." Against the Current (September-October).

Bukharin, Nicolai

1971 La economía mundial y el imperialismo. Buenos Aires: Pasado y Presente.

Chesnais, François

1994 La mondialisation du capital. Paris: Syros.

1998 "Les dangereux mirages de la relative fonctionnalité de la finance." Critique Comuniste, no. 151 (Winter).

Henwood, Doug

1996 "Pos what?" Monthly Review 48(4).

Holloway, John

1998 "El Manifiesto Comunista." Cuadernos del Sur, no. 26 (April).

Husson, Michel

1997 "Contre le fetichisme de la finance." Critique Comuniste, no. 149 (Summer).

Katz, Claudio

1998 "Crisis y revolución tecnológica a fin de siglo." Realidad Económica, no. 154 (FebruaryMarch).

Lenin, $\mathrm{V}$.

1973 El imperialismo, fase superior del capitalismo. Buenos Aires: De Anteo.

Luxemburg, Rosa

1968 La acumulación del capital. Buenos Aires: S/E.

Malloy, Mary

1995 “On Brenner's politics of U.S. decline." Against the Current (July-August).

Mandel, Ernest

1967 La formación del pensamiento económico de Marx. Mexico City: Siglo XXI. Marx, Karl

1973 El capital. Vol. 1. Mexico City: Fondo de Cultura Económica.

Marx, Karl and Frederick Engels

1967 El Manifiesto Comunista. Buenos Aires: Claridad.

Michalet, Charles Albert

1976 Le capitalisme mondial. Paris: PUF.

Philon, Dominique

1997 "Les enjeux de la globalisation financière," in Mondialisation: Au-delà des mythes. Paris: La Découverte.

Sivanandan, A.

1997 "Capitalism, globalization, and epochal shifts." Monthly Review (February).

Trotsky, Leon

1969 La revolución tracionada. Mexico City: Ediciones del Sol.

1972 Resultados y perspectivas. Buenos Aires: De Cepe. 